\title{
ANTIBACTERIAL, ANTIFUNGAL, ANTIOXIDANT ACTIVITY AND POLYPHENOL CONTENT OF AERIAL PARTS AND BULBS OF ALLIUM SCHUGNANICUM
}

\author{
S. SATOROV ${ }^{1}$, F. MIRZOEVA ${ }^{1}$, SH. KURBONBEKOVA², SH. SATOROV², M. VAKHIDOVA ${ }^{3}$, V. DUSHENKOV ${ }^{4}$ \\ 1 Department of Microbiology, Immunology and Virology, Avicenna Tajik State Medical University, Dushanbe, Republic of Tajikistan \\ 2 Institute of Botany, Physiology and Genetics of Plants, National Academy of Sciences of Tajikistan, Dushanbe, Republic of Tajikistan \\ 3 Department of Plant Biology, School of Environmental and Biological Sciences, Rutgers University, New Brunswick, NJ, USA \\ 4 Department of Natural Sciences, Hostos Community College, City University of New York, Bronx, NY, USA
}

Objective: To study of antibacterial, antifungal and antioxidant activity, and content of polyphenols in the bulb and aerial parts of an endemic species of onion A. schugnanicum.

Methods: An ethanol-based extract was prepared from fresh plants. Total polyphenolic content (Folin) and ABTS antioxidant capacity assays were used to characterized extracts. Extracts obtained from bulbs, peduncle, and seeds demonstrated antibacterial activity against the reference Staphylococcus aureus (ATCC 4929), Pseudomonas aeruginosa (ATCC 4930) and Klebsiella pneumoniae (ATCC 4927) strains, as well as against the hospital strains of the same types of bacteria, i.e. strains isolated from inpatient surgical patients.

Results: The study found that ethanol extracts obtained from all organs of $A$. schugnanicum exhibit high inhibitory activity against the hospital and reference strains. In relation to reference then to hospital strains ethanol extracts were more active. The greatest bactericidal effect on both strains was exhibited by the bulb extracts. The extracts did not inhibit the growth of Escherichia coli. Fungicidal action characterized by growth inhibition zone of bulb and seeds, respectively. The extract obtained from the peduncle of this plant exhibited smaller inhibitory activity. The antioxidant capacity of A. schugnanicum different parts are shown in all the parts had a large antioxidant activity with dominating antioxidant capacity in seeds. The highest polyphenol level was found in the bulb.

Conclusions: The study showed that $A$. schugnanicum may be a prospective species for developing botanical therapeutics.

Keywords: Allium schugnanicum, medicinal plants, growth inhibition, extracts, antioxidant activity, hospital strains of bacteria, reference strains of bacteria.

For citation: Satorov S, Mirzoeva F, Kurbonbekova Sh, Satorov Sh, Vakhidova M, Dushenkov V. Antibacterial, antifungal, antioxidant activity and polyphenol content of aerial parts and bulbs of Allium schugnanicum. Vestnik Avitsenny [Avicenna Bulletin]. 2020;22(1):98-105. Available from: https://doi. org/10.25005/2074-0581-2020-22-1-98-105.

\section{АНТИБАКТЕРИАЯЬНАЯ, ПРОТИВОГРИБКОВАЯ, АНТИОКСИДАНТНАЯ АКТИВНОСТЬ И СОДЕРЖАНИЕ ПОЛИФЕНОЛОВ В ЯУКОВИЦЕ И НАДЗЕМНЫХ ЧАСТЯХ АLLIUМ SСНUGNANICUM}

\author{
С. САТОРОВ ${ }^{1}$, Ф. МИРЗОЕВА ${ }^{1}$ Ш. КУРБОНБЕКОВА ${ }^{2}$ Ш. САТОРОВ ${ }^{3}$, М. ВАХИДОВА 3 , В. ДУШЕНКОВ ${ }^{4}$
}

1 Кафедра микробиологии, иммунологии и вирусологии, Таджикский государственный медицинский университет им. Абуали ибни Сино, Душанбе, Республика Таджикистан

2 Институт ботаники, физиологии и генетики растений Национальной академии наук Таджикистана, Душанбе, Республика Таджикистан

3 Кафедра биологии растений, Школа экологических и биологических наук, Ратгерский Университет, Нью Брансвик, США

4 Кафедра естественных наук, Хостоский общественный колледж, Городской Университет Нью-Йорка, Нью-Иорк, США

Цель: изучение антибактериальной, противогрибковой, антиоксидантной активности и содержания полифенолов в луковице и надземных частях эндемичного вида лука Allium schugnanicum.

Материал и методы: Исходные этанольные экстракты были получены из свежих растений. Были изучены общий состав полифенолов (Ғоlin) и ABTS антиоксидантная активность растения. Экстракты, полученные из луковицы, стебля и семян демонстрировали высокую антибактериальную активность относительно трёх видов стандартных музейных микроорганизмов (тест штаммов): Staphylococcus aureus (ATCC 4929), Pseudomonas aeruginosa (АТCC 4930) и Klebsiella pneumoniae (АТСС 4927), а также против госпитальных штаммов этих же видов бактерий, т.е. штаммов, изолированных от стационарных хирургических пациентов.

Результаты: изучение показало, что этанольные экстракты, полученные из различных частей лука Allium schugnanicum проявляли высокую ингибирующую активность в отношение как госпитальных, так и референсных штаммов бактерий. Allium schugnanicum проявлял более высокую антибактериальную активность к референсным штаммам, чем к штаммам госпитального происхождения. Наибольшей антибактериальной активностью, как к госпитальным, так и к референсным штаммам характеризовался экстракт, полученный из луковицы. Экстракты не подавляли роста Escherichia coli. Противогрибковая активность также проявлялась у луковицы и семян, а меньшую фунгицидную активность показал экстракт из стебля. Антиоксидантная активность Allium schugnanicum проявлялась в различных частях с доминирующей антиоксидантной активностью в семенах. Наиболее высокое содержание полифенолов обнаружилось в луковице.

Заключение: исследование показало, что Allium schugnanicum может быть перспективным лекарственным растением в фитотерапии. Ключевые слова: Allium schugnanicum, лекарственные растения, ингибирование роста, экстракты, антиоксидантная активность, госпитальные итаммы бактерий, референсные итаммы бактерий.

Для цитирования: Satorov S, Mirzoeva F, Kurbonbekova Sh, Satorov Sh, Vakhidova M, Dushenkov V. Antibacterial, antifungal, antioxidant activity and polyphenol content of aerial parts and bulbs of Allium schugnanicum. Vestnik Avitsenny [Avicenna Bulletin]. 2020;22(1):98-105. Available from: https://doi. org/10.25005/2074-0581-2020-22-1-98-105. 


\section{INTRODUCTION}

Plants as sources of antibiotics. The development of bacterial resistance to the currently used antibiotics necessitates the search for new antibacterial drugs [1]. The emergence and rapid spread of hospital and socially significant microorganisms, which quickly acquire the drug polyresistance and cause severe clinical forms of infectious pathology is of particular concern [2, 3]. Gram-positive bacteria such as Staphylococcus aureus are mainly responsible for postoperative wound infections, toxic shock syndrome, endocarditis, osteomyelitis, food poisoning as well as many pathologies of women in labor and newborns [4-7]. Gram-negative bacteria, in particular Escherichia coli, a representative of the normal intestinal microbial flora, may enter an uncharacteristic habitat and impact various organs and tissues, causing infections of the lower urinary tract, otitis, and septicemia. Other types of gram-negative microorganisms like Pseudomonas aeruginosa and various types of Klebsiella, are also frequent etiological factors of nosocomial infections and are characterized by wide polyresistance $[8,9]$.

The current situation, along with the high cost of synthetic drug production and their possible adverse effects on the human body compared with herbal preparations, forces scientists to intensify the search for new antimicrobial compounds from various sources [7, 10-13].

People around the world used plants to combat infections for thousands of years [14-16], even without knowing about the existence of microorganisms. It is difficult to know when exactly this practice has begun due to the lack of written or other material evidence. Some plants were used because people learned by trial and error about their healing properties. Other plants were used in cooking, and along with their taste, they also demonstrated antimicrobial effects [17-19]. These include Allioideae, a subfamily of plants in the family Amaryllidaceae, order Asparagales. Various species of this group have been used since ancient times in cooking and medicine [20]. People in China, Egypt, Persia, India, and other countries knew about the antimicrobial properties of garlic, one of the representatives of this family [21-23]. As per historical overview by Lawson [24] the medicinal use of garlic, which began about 5,000 years ago, was first recorded by both the Sumerians of Mesopotamia as well as by the people of ancient India. Garlic was also of great importance in Egypt, where it has been found preserved in Pharaohs' tombs and the Egyptian Ebers Codex of 1,550 BC mentions the use of garlic. The Greeks used garlic to strengthen Olympic athletes and to treat battle wounds. In World War II, Russia, where garlic use has long been popular, used it again for soldiers' wounds when they ran out of penicillin, which resulted in the nickname of "Russian penicillin".

Allium. Botanical description. Significance and use. Genus Allium (Onion) comprises a large group of onion- or garlic-scented bulbous herbs of the Amaryllidaceae family. Allium species have very characteristic flowers with six petals pungent linear leaves. Black seeds maturate in dry capsule fruits. Onion species are found in a diverse spectrum of habitat almost everywhere from highlands to the coast of the seas. The steppe and semi-desert of lowlands and mountains are known for a large variety of Allium representatives including many endemic species [25]. Among the species of the Allium genus, there are many valuable plants: food, medicinal, and ornamental. Even Dioscorides and Avicenna describe the beneficial properties of onions.

The importance of onions as vitamin-bearing plants has also been long recognized by humans. Alliums are characterized by the presence in the tissues of volatile sulfur-containing oils that deter- mine their characteristic onion or garlic odor, which have a strong bactericidal effect. Beneficial properties of Allium are often linked to the organosulfur compounds [26]. Bulbs and leaves at the same time have several vitamins including Vitamin $C$ (ascorbic acid), Vitamin $B_{1}$ (thiamin), Vitamin $B_{2}$ (riboflavin), Vitamin $B_{3}$, Vitamin $B_{6}$ (piridoxine), Folate, Vitamin $\mathrm{E}$ ( $\alpha$-tocopherol), Vitamin $\mathrm{K}$ (phylloquinone), minerals ( $\mathrm{Ca}, \mathrm{Fe}, \mathrm{Mg}, \mathrm{P}, \mathrm{K}, \mathrm{Na}, \mathrm{Zn}, \mathrm{Se}$ ), and essential oils [27]. All this determines the widespread use of onions in medicine.

Their bactericidal properties of Allium, which have long been used in traditional medicine, are best known. Modern medicine uses about ten drugs from various types of onions. The most common are Allylchep and Allylglycer. Their main purpose is the treatment of infectious diseases. In addition, they enhance motor and secretory activity. Mannitol, extracted from onions, is a product intended for nutrition for diabetics [28]. The Natural Medicines Comprehensive Database, one of the most comprehensive and reliable natural medicine resources, lists 746 products containing onion [29] and 3,791 products containing garlic [30].

Over 30 different wild onions grow in Tajikistan, of which more than 14 species found in Badakhshan. Among those are A. afghanicum Wendelbo, A. carolinianum DC., A. Ramosum L., A. oshaninii $O$. Fedtsch., A. schugnanicum Vved. Many of the species are endemic and their biological activity, including antimicrobial activity, was not studied [31, 32].

Among these species, Allium schugnanicum Vved., which grows at an altitude of $2100-2600 \mathrm{~m}$, is of great economic interest, including medicinal interest [33]. This species, a narrow endemic from shady montane slopes of western Pamir mountain massifs, belongs to Allium L. subg. Melanocrommyum. The classification and phylogeny of this group were recently extensively reviewed [34-36].

\section{PURPOSE OF RESEARCH}

The study of antimicrobial, antifungal and antioxidant activity of ethanol extract from different parts of $A$. schugnanicum.

\section{MATERIALS AND METHODS}

Plant material. The object of the study was the bulb, peduncle and seeds of $A$. schugnanicum, collected at the Pamir Botanical Garden of the Gorno-Badakhshan Autonomous Region (GBAR), the Republic of Tajikistan (altitude $-2300 \mathrm{~m}$ ). Ethanol extracts obtained from various parts of $A$.

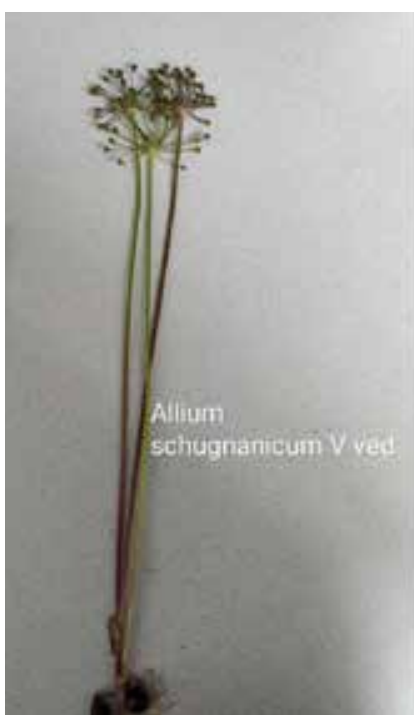
schugnanicum, plant with well known antimicrobial activity, were used for comparison in the study of antimicrobial and antifungal properties (Fig. 1).

Sample preparation. Working concentration and paper discs were prepared according to the method developed at Rutgers University (Skubel, Dushenkov et al, 2018). Briefly, two grams of the plant materi-

Fig. 1 Allium schugnanicum Vved. 
al was weighed and cut into small pieces with a knife. The sample was placed in a marked by a permanent marker $20 \mathrm{ml}$ scintillation vial. With a clean syringe, four $\mathrm{ml}$ of $95 \%$ ethanol was measured and added to the vial. Grinding and simultaneous extraction of the plant tissue was performed with the specially adapted cordless, variable speed, Dremel rotary tool, Model $8220,12 \mathrm{~V}$ for 5 minutes. The contents of the vial were settled for at least 5 minutes and then filtered. $90 \mu \mathrm{l}$ of the plant extract were instilled onto each $10 \mathrm{~mm}$ in diameter Whatman1glass microfiber filters, Grade GF/D (Whatman \# $1823 \pm 010$, purchased from Millipore Sigma) carefully monitoring the distribution of the extract so that it was not particularly concentrated in one section of the disc. Discs were dried at room temperature. When air-dried, discs were placed inside the plastic bags pre-labeled with an identification number.

Culture preparation. The antimicrobial activity of plant extracts was determined against four types of pathogenic standard reference microorganisms (reference strains): Klebsiella pneumoniae (ATCC 4927), Escherichia coli (ATCC 4928), Staphylococcus aureus (ATCC 4929), and Pseudomonas aeruginosa (ATCC 4930) as well as hospital strains of the same types of bacteria, i.e. strains isolated from inpatient surgical patients. Antifungal activity was studied against fungi of the genus Candida, the most common cause of fungal infection. The bacterial strains were scattered over the surface of the corresponding nutrient media in Petri dishes: $S$. aureus - on staphyloagar, E. coli - on Endo medium, P. aeruginosa and K. pneumoniae - on simple agar. Subsequently, to obtain a pure culture, one isolated colony of a certain type was reseeded onto the corresponding slant agar medium. McFarland turbidity $10 \mathrm{IU}$ was used to prepare suspension (inoculum) of 24-hour bacterial cultures of the studied strains with the final concentration of microorganisms $2 \times 10^{6}$ $\mathrm{CFU} / \mathrm{ml}$.

\section{The study of antimicrobial and antifungal properties}

Chemicals. The chemicals used in the analysis were obtained respectively from Sigma-Aldrich St. Louis, MO: Folin\&Ciocalteu's phenol reagent and ABTS [2, 2 azino-bis (3-ethylbenzo-thiazoline-6-sulfonic acid)], Fisher Scientific Co., Fair Lawn, NJ: Sodium Carbonate, JTBaker Chemical Co., Phillipsburg, NJ: Potassium Persultfate, and Acros Organics, Morris Plains, NJ: Gallic Acid Monohydrate.

Screens-To-Nature assays. Both total polyphenolic content (Folin) and ABTS antioxidant capacity assays are commonly used for medicinal plants methanolic extracts characterization (Gonçalves, Moreira et al, 2017).

Total polyphenolic content (Folin) and ABTS antioxidant assays are part of the Screens-To-Nature (STN) technology assays panel adopted by the Global Institute for BioExploration (GIBEX) (Dushenkov and Raskin, 2008; Kellogg, Joseph et al, 2010). The STN technology is aimed at overcoming the controversies associated with the conventional approach of bringing plant material (nature) from the developing regions to laboratories in the developed world for testing. It makes possible the initial evaluation of locally grown plant material in just a few days without transporting extracts across international borders. The STN kit consists of a number of field-deployable assays requiring only two grams of fresh plant tissue (root, stem, leaves, etc.). All STN bioassays have been lab-validated and proved to be a viable tool for early-stage discovery of bioactive substances in plants, eliminating the destructive harvesting of plants required for the offsite screening.

Total polyphenolic content (Folin) assay. The protocol based on Folin-Ciocalteu reagent was used to estimate total phenolic content (TPC) in plant tissues with reliable results (Blainski, Lopes et al, 2013). The total polyphenolic content (Folin) assay described elsewhere (Ainsworth and Gillespie, 2007; Gonçalves, Moreira et al, 2017) was performed with some modifications. Briefly, an aliquot of the plant extract $(200 \mu \mathrm{L})$ was mixed with $200 \mu \mathrm{L} 1 \mathrm{~N}$ Folin-Ciocalteu reagent extract in Eppendorf tubes. After 10 minutes at room temperature, $300 \mu \mathrm{l}$ of the $20 \% \mathrm{Na}_{2} \mathrm{CO}_{3}$ solution was added into each tube. All tubes were well shaken and kept at $40^{\circ} \mathrm{C}$ for 20 minutes, thereafter the tubes were quickly cooled to the room temperature and the absorbance was measured at $760 \mathrm{~nm}$ by a portable USB-650VIS-NIR Red Tide Spectrometer linked to the SpectraSuite software. The concentration of TPC was calculated using gallic acid (0-20 $\mu \mathrm{g}$ $\mathrm{mL}^{-1}$ ) as a standard. When needed the extracts were diluted to obtain results within the linear range of the gallic acid standard curve. The final results were expressed as $\mu \mathrm{g}$ gallic acid equivalents (GAE) per

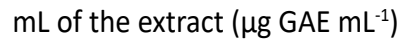

ABTS antioxidant assay. The antioxidant assay was performed based on a technique broadly used in plant sample analyses (Gonçalves, Moreira et al, 2017) as described by Walker and Everette (Walker and Everette, 2009) with some modifications. Briefly, the ABTS [2, 2 azino-bis (3-ethylbenzo-thiazoline-6-sulfonic acid)] radical scavenging activity of plant extracts was determined through reaction with potassium persulfate $\left(\mathrm{K}_{2} \mathrm{~S}_{2} \mathrm{O}_{8}\right)$. Potassium persulfate converts $\mathrm{ABTS}$ to its radical cation and the initially colorless solution turns dark green. The ABTS radical cation is reactive towards antioxidants, which, when added, convert the dark green ABTS radical cation back to its colorless neutral form. Trolox (6-Hydroxy-2, 5, 7, 8-tetramethylchroman-2-carboxylic acid) solution was used as a reference standard. Absorbance was read at $734 \mathrm{~nm}$ using a portable USB-650-VIS-NIR Red Tide Spectrometer linked to the Spectra Suite software. When needed the extracts were diluted to obtain results within the linear range of the Trolox standard curve. The antioxidant capacity results were expressed as " $\mu \mathrm{g} \mathrm{mL^{-1 }}$ Trolox equivalents (TE)".

\section{RESEARCH RESULTS}

Antibacterial and fungicidal activity of the extracts. The study found that ethanol extracts obtained from all organs of $A$. schugnanicum exhibit high inhibitory activity against the hospital and reference strains of $P$. aeruginosa. The greatest bactericidal effect on both strains was exhibited by the bulb extract. As can be seen from Table 1, the zone of growth inhibition of the reference strain around the paper disk, impregnated with the extract from the bulb, was 15 $\mathrm{mm}$. For the hospital strain, this indication did not exceed $13 \mathrm{~mm}$. Regarding the reference strain, the same inhibitory activity was characterized by ethanol extracts from the peduncle and seeds $-12 \mathrm{~mm}$ each, which is slightly larger than the zone of growth inhibition of the hospital strain $-10 \mathrm{~mm}$ and $9 \mathrm{~mm}$, respectively. Similar bactericidal activity was observed in relation to strains of Klebsiella. Thus, the inhibitory growth zone of the reference strain was equal to the growth inhibition zone of a similar strain of $P$. aeruginosa, i.e. $15 \mathrm{~mm}$. Bactericidal activity relative to this strain also did not differ in extracts from the peduncle and seeds $-10 \mathrm{~mm}$ inhibition growth zone of the reference; $9 \mathrm{~mm}$ and $8 \mathrm{~mm}$, respectively, of the hospital strain.

Noteworthy is the relatively low bactericidal activity of ethanol extracts obtained from all organs against $S$. aureus strains. In particular, the diameter of the zone of growth inhibition of the reference strain around the disk with the bulb extract was just $11 \mathrm{~mm}$, which is $4 \mathrm{~mm}$ less than that of the P. aeruginosa and Klebsiella strains. Though, the antibacterial activity of extracts from the peduncle and seeds was close to that of the two tested microorganisms listed above and ranged from $7 \mathrm{~mm}$ to $10 \mathrm{~mm}$. Notably, we did not record inhibition to $E$. coli growth by any of the tested extracts. 
Table 1 Antibacterial activity of extracts of A. schugnanicum

\begin{tabular}{|c|c|c|c|c|c|c|c|c|}
\hline \multirow{3}{*}{ Part of plant } & \multicolumn{2}{|c|}{ P. aeruginosa } & \multicolumn{2}{|c|}{ K. pneumoniae } & \multicolumn{2}{|c|}{ S. aureus } & \multicolumn{2}{|c|}{ E. coli } \\
\hline & \multicolumn{8}{|c|}{ Zone of inhibition around of disk (in $\mathrm{mm}$ ) } \\
\hline & Reference & Hospital & Reference & Hospital & Reference & Hospital & Reference & Hospital \\
\hline Bulb & 15 & 13 & 15 & 12 & 11 & 9 & 0 & 0 \\
\hline Peduncle & 12 & 10 & 10 & 9 & 10 & 8 & 0 & 0 \\
\hline Seeds & 12 & 9 & 10 & 8 & 8 & 7 & 0 & 0 \\
\hline
\end{tabular}

\section{Inhibition zone for Candida sp.}

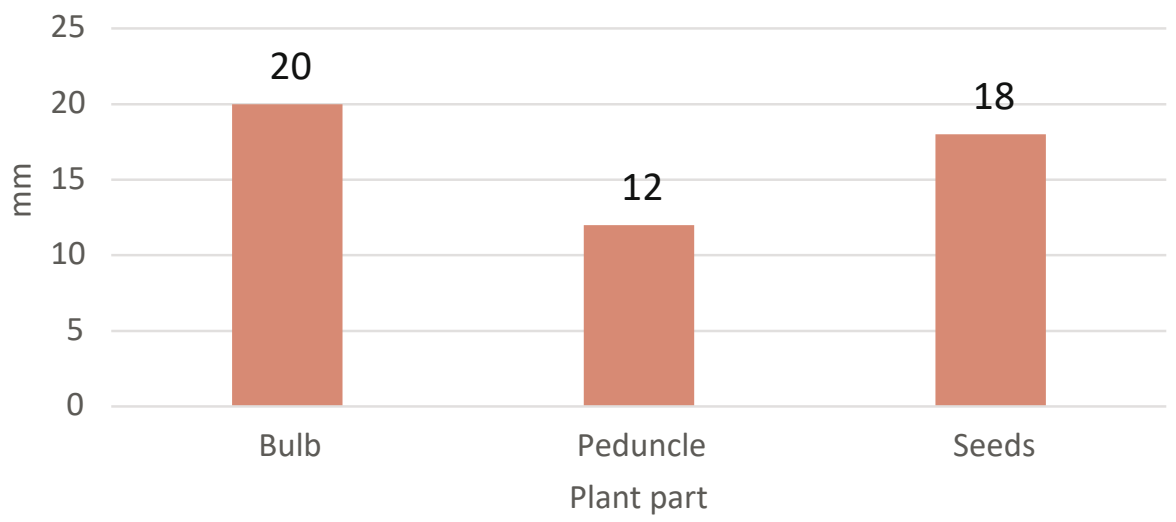

Fig. 2 Antifungal activity of A. schugnanicum extracts
Research results indicate that ethanol extracts of $A$. schugnanicum are characterized by a diverse spectrum of fungicidal action.

As shown in Fig. 2, the extracts from the bulb and seeds had the greatest fungicidal activity: the growth inhibition zone around paper disks was $20 \mathrm{~mm}$ and $18 \mathrm{~mm}$, respectively. The extract obtained from the peduncle of this plant exhibited smaller inhibitory activity $(12 \mathrm{~mm})$.

The antioxidant capacity of $A$. schugnanicum different parts is shown in Fig. 3. All the parts had a large antioxidant activity with dominating antioxidant capacity in seeds $\left(95.4 \mu \mathrm{g} \mathrm{mL}^{-1} \mathrm{TE}\right)$ and bulb (94.6 $\mu \mathrm{g} \mathrm{mL} \mathrm{L}^{-1} \mathrm{TE}$ ). Peduncle antioxidant capacity was lower at 81.2 $\mu \mathrm{g} \mathrm{mL^{-1 }} \mathrm{TE}$.

The total polyphenolic content is dramatically different in tested parts of $A$. schugnanicum (Fig. 4). The absolute majority of polyphenols are concentrated in bulb with total polyphenolic content measured at $39.49 \mu \mathrm{g} \mathrm{GAE} \mathrm{mL}{ }^{-1}$. As shown in Fig. 3 peduncle and seeds had the total polyphenolic content measured respectively only at $5.44 \mu \mathrm{g} \mathrm{GAE} \mathrm{mL} \mathrm{L}^{-1}$ and $2.38 \mu \mathrm{g} \mathrm{GAE} \mathrm{mL}{ }^{-1}$.

\section{DISCUSSION}

The antibacterial and antifungal effects of the most common species of the Allium genus - Allium cepa (onions), Allium sativum (garlic), Allium suworowii (anzur) and some other widely used onion varieties have been known since historical times [37, 38]. There is sufficient scientific information on their biological properties, including bactericidal and antioxidant activities, as well as the content of polyphenols [39-41]. Recently, more attention was devoted to a variety of wild Allum species [42]. However, despite the widespread onion plants in various climatic areas of our country, their bactericidal and antifungal activity was not studied before the start of this study.

Based on the foregoing, we were set a goal to study the antibacterial, antifungal, antioxidant activity, as well as the content of common polyphenols of one of the endemic species of onion plants - A. schugnanicum. It mainly grows on the territory of the Shugnan ridge of the Gorno-Badakhshan Autonomous Region of the Republic

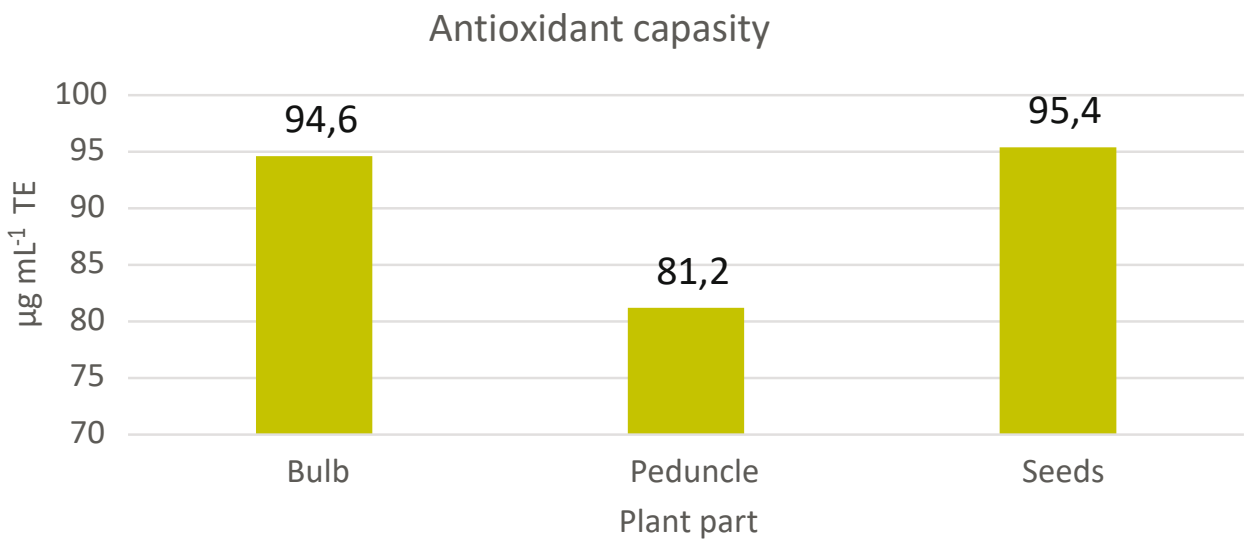

Fig. 3 Antioxidant capacity of A. schugnanicum extracts 
Total polyphenolic content

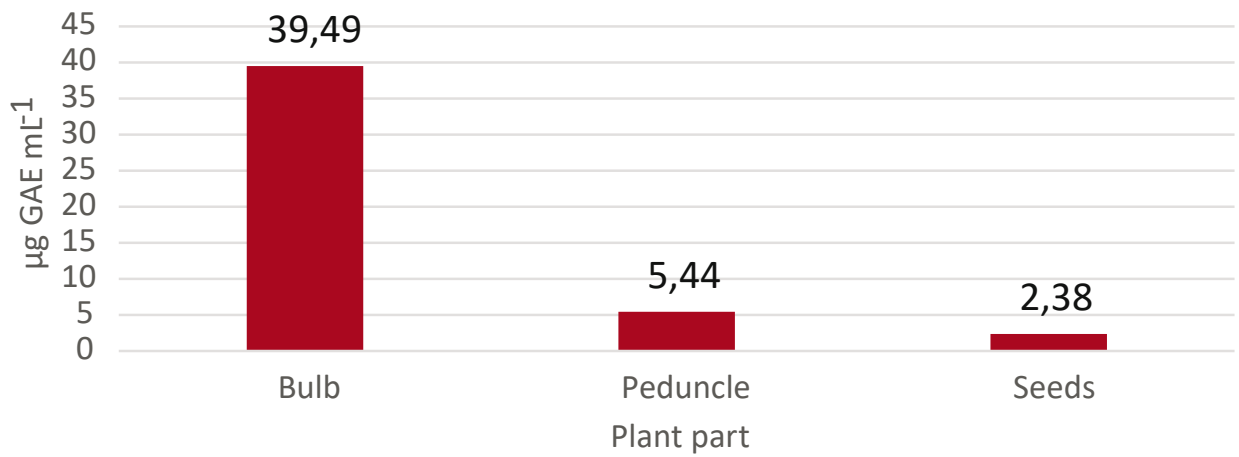

Fig. 4 Total polyphenolic content of A. schugnanicum extracts

of Tajikistan and the northern regions of Afghanistan at an altitude of $2100 \mathrm{~m}$ above sea level.

The bactericidal and antifungal activity of the extracts against gram-positive and gram-negative bacteria was determined by the disk diffusion method by measuring the growth inhibition zone of test microorganisms around paper disks.

Overall antibacterial activity of $A$. schugnanicum was more pronounced against reference strains compared to hospital strains. In our evaluation bulb extract demonstrated the highest antibacterial activity, followed by peduncle and seeds extracts. The highest antifungal activity was also observed for bulb extract (Fig. 2). The seeds extract exhibit slightly lower antifungal activity. The lowest inhibition zone in Candida experiments was observed for peduncle $(12 \mathrm{~mm})$. High antibacterial and antifungal activity of bulb extracts may be connected to a high level of total polyphenols $(39.49 \mu \mathrm{g}$ GAE $\left.\mathrm{mL}^{-1}\right)$. The observed antioxidant capacity was similar for all $A$. schugnanicum parts with a peduncle having the lower levels of antioxidant capacity (Fig. 3). In general, the bulb had the most promising health beneficial properties including antibacterial, antifungal capabilities and high antioxidant capacity paired with high total polyphenol level.

Due to the lack of data on the bactericidal activity of $A$. schugnanicum in the scientific literature and taking into account the presence of common biological characters in representatives of the genus Allium, we compared our results with data from other authors who studied similar properties of other types of onions. The analysis shows that our data partially agree with the results of a study by the authors $[43,44]$ who studied the antibacterial activity of six Allium species against gram-positive and gram-negative microorganisms, which report the bactericidal effect of extracts of all the studied species against $E$. coli, the main representative of the normal intestinal microbial flora. In our experiments, the extract of the endemic species $A$. schugnanicum did not affect $E$. coli growth.

A comparative analysis of antibacterial and antifungal activity indicates that extracts obtained from all organs of $A$. schugnanicum are characterized by higher fungicidal activity compared to antibacterial activity. Here, our data are consistent with the results of most authors from Asia, Africa and Latin America [45, 46]. Some authors report the lack of antifungal activity of extracts of various onion va- rieties, in particular, garlic [47]. However, the objects examined by us and foreign colleagues belonged to different plant species of the genus Allium and additional and deeper studies are required.

It is known that plants are considered as a promising source of biologically active compounds possessing anti-oxidative activity. However, in various plants, including representatives of the genus Allium, there is a large variability of antioxidant activity [48, 49], therefore it becomes necessary to determine the antioxidant activity of each test plant $[50,51]$. An analysis of the literature data suggests that the content of substances of a phenolic and polyphenolic nature plays a role in the level of antioxidant activity [52-55]. Based on the available information, we studied the antioxidant activity and the presence of polyphenols in various parts of $A$. schugnanicum. Our studies show that extracts obtained from the underground and aboveground parts of this plant exhibit approximately the same antioxidant activity. Differences in the concentrations of polyphenolic compounds in extracts from various organs were revealed.

Further research allowed us to establish some correlation between the content of total polyphenols and their bactericidal activity, which was more pronounced in relation to a strain of fungi of the genus Candida. Here, the results of our study are consistent with published data [56] which studied the possible relationship between the content of phenolic compounds and the antibacterial activity of the most common species of the genus Allium.

\section{CONCLUSIONS}

A study of antibacterial, antifungal and antioxidant activity, as well as the content of polyphenols in the bulb and aerial parts, was conducted for the first time for $A$. schugnanicum, an endemic species of onion representatives growing on the territory of the GBAR of the Republic of Tajikistan. Bulb ethanol extract of this species is characterized by more pronounced bactericidal and fungicidal activity compared to other parts. Extracts from all parts of $A$. schugnanicum have similar antioxidant activity. The highest concentration of phenolic compounds was found in the bulb extract. A correlation between the content of polyphenols in plant materials and the bactericidal activity of the studied extract was revealed. The study showed that $A$. schugnanicum may be a prospective species for developing botanical therapeutics. 


\section{REFERENCES}

1. Alam MM, Islam M, Wahab A, Billah M. Antimicrobial resistance crisis and combating approaches. Journal of Medicine. 2019;20(1):38-45.

2. Sukhorukova MV, Edelstein MV, Skleenova EYu, Ivanchik NV, Shek EA, Dekhnich, i dr. Antibiotikorezistentnost' nozokomial'nykh shtammov Pseudomonas aeruginosa v statsionarakh Rossii: rezul'taty mnogotsentrovogo epidemiologicheskogo issledovaniya "MARAFON» [Antimicrobial resistance of nosocomial Pseudomonas aeruginosa isolates in Russia: results of multicenter epidemiological study "MARAPHON» 2013-2014.] Klinicheskaya mikrobiologiya i antimikrobnaya khimioterapiya. 2017;19(1):37-41.

3. Mazankova LN, Grigoryev K. Infektsionnye zabolevaniya u detey: rol' v vozniknovenii somaticheskoy patologii [Infectious diseases of children: role in the occurrence of somatic pathology]. Detskiye infektsii. 2013;12(3):3-8.

4. Mitrofanova NN, Melnikov VL, Sletov AM. Rezul'taty monitoringa i vidovogo sostava i osnovnykh biologicheskikh kharakteristik mikrobiotsenozov mnogoprofil'nogo statsionara [Results of monitoring and species composition and basic biological characteristics of microbiocenoses of a multidisciplinary hospital]. Izvestiya vysshikh uchebnykh zavedeniy. Povolzhskiy region. Meditsinskie nauki. 2009;4:90-8.

5. Wang L, Ruan S. Modeling nosocomial infections of methicillin-resistant Staphylococcus aureus with environment contamination. Scientific Reports. 2017;7(1):1-12.

6. Tong SY, Davis JS, Eichenberger E, Holland TL, Fowler VG. Staphylococcus aureus infections: epidemiology, pathophysiology, clinical manifestations, and management. Clinical Microbiology Reviews. 2015;28(3):603-61.

7. Nazir A, Malik K, Qamar H, Basit MH, Liaqat A, Shahid M, et al. A review: Use of plant extracts and their phytochemical constituents to control antibiotic resistance in S. aureus. Pure and Applied Biology (PAB). 2020;9(1):720-7.

8. Ivanov DV, Bunyatyan ND, Uteshev DB, Korsun LV. Osobennosti antibiotikochuvstvitel'nosti vazhneyshikh gramotritsatel'nykh vozbuditeley nozokomial'nykh infektsiy [Features of antibiotic sensitivity of the most important gram-negative causative agents of nosocomial infections]. Vestnik RGMU. 2009;2:26-9.

9. Tapalskiy DV, Osipov VA, Zhavoronok SV. Karbapenemazy gramotritsatel'nykh bakteriy: rasprostranenie i metody detektsii [Carbapenemases of gram-negative pathogens: spread and methods of detection]. Meditsinskiy zhurnal. 2012;2:10-6.

10. Martin KW, Ernst E. Herbal medicines for treatment of bacterial infections: a review of controlled clinical trials. Journal of Antimicrobial Chemotherapy. 2003;51(2):241-6.

11. Djeussi DE, Noumedem JA, Seukep JA, Fankam AG, Voukeng IK, Tankeo SB, et al. Antibacterial activities of selected edible plants extracts against multidrug-resistant Gram-negative bacteria. BMC Complementary and Alternative Medicine. 2013;13(1):164.

12. Srivastava J, Chandra H, Nautiyal AR, Kalra SJ. Antimicrobial resistance (AMR) and plant-derived antimicrobials (PDA $\mathrm{m} \mathrm{s}$ ) as an alternative drug line to control infections. 3 Biotech. 2014;4(5):451-60.

13. Mahato TK, Sharma K. Study of medicinal herbs and its antibacterial activity: A review. Journal of Drug Delivery and Therapeutics. 2018;8(5-s):47-54.

14. Dushenkov V, Graf BL, Lila MA. Botanical therapeutics in the modern world. In: Sidelnikov NI, ed. Biological characteristics of medicinal and aromatic plants and role of these plants in medicine. Moscow, RF: Russia FGBNU, VILAR; 2016. p. 50-4.

15. Satorov S, Mirzoeva F, Satorov S, Vakhidova M, Dushenkov V. Comparative characteristics of antibacterial activity of plants growing in the central part of the Republic of Tajikistan. Vestnik Avitsenny [Avicenna Bulletin]. 2019;21(4):643-54. Available from: https://doi.org/10.25005/2074-05812019-21-4-643-654.

16. Subramani $R$, Narayanasamy $M$, Feussner K-D. Plant-derived antimicrobials to fight against multi-drug-resistant human pathogens. 3 Biotech. 2017;7(3):172.

17. Santas J, Almajano MP, Carbó R. Antimicrobial and antioxidant activity of crude onion (Allium cepa L.) extracts. International Journal of Food Science \& Technology. 2010;45(2):403-9.

18. Eltaweel $\mathrm{M}$, ed. Assessment of antimicrobial activity of onion extract (Allium серa) on Staphylococcus aureus; in vitro study. International Conference on Chemical, Agricultural and Medical Sciences. Dec; 2013.

19. Suleria HAR, Butt MS, Khalid N, Sultan S, Raza A, Aleem M, et al. Garlic (Allium sativum): diet based therapy of $21^{\text {st }}$ century - a review. Asian Pacific Journal of Tropical Disease. 2015;5(4):271-8.
20. Ekşi G, Özkan AMG, Koyuncu M. Garlic and onions: An eastern tale. Journal of Ethnopharmacology. 2020:112675.

21. Viswanathan V, Phadatare A, Mukne A. Antimycobacterial and antibacterial activity of Allium sativum bulbs. Indian Journal of Pharmaceutical Sciences. 2014;76(3):256.

22. Hannan A, Ullah MI, Usman M, Hussain S, Absar M, Javed K. Anti-mycobacterial activity of garlic (Allium sativum) against multi-drug resistant and non-multi-drug resistant Mycobacterium tuberculosis. Pak J Pharm Sci. 2011;24(1):81-5.

23. Singh R, Singh K. Garlic: A spice with wide medicinal actions. Journal of Phar macognosy and Phytochemistry. 2019;8(1):1349-55

24. Lawson LD. Garlic: a review of its medicinal effects and indicated active compounds. In: Phytomedicines of Europe: ACS Publications; 1998. p. 176-209.

25. Karomatov ID, Akramova NSh. The prospects of application of garlic at diseases of the musculoskeletal system. Biologiya i integrativnaya meditsina. 2019;4:78-84.

26. Putnik P, Gabrić D, Roohinejad S, Barba FJ, Granato D, Mallikarjunan K, et al. An overview of organosulfur compounds from Allium spp.: From processing and preservation to evaluation of their bioavailability, antimicrobial, and anti-inflammatory properties. Food Chemistry. 2019;276:680-91.

27. Sharifi-Rad J, Mnayer D, Tabanelli G, Stojanović-Radić Z, Sharifi-Rad M, Yousaf $Z$, et al. Plants of the genus Allium as antibacterial agents: From tradition to pharmacy. Cellular and Molecular Biology. 2016;62(9):57-68.

28. Manukyan KA, Senchenko SP, Kompantseva EV. Opredelenie alliina v nadzemnoy chasti luka medvezh'ego (Allium ursinum L.) metodom kapillyarnogo elektroforeza [Determination of alliin in the aerial part of bear onions (Allium ursinum L.) by capillary electrophoresis]. Izvestiya Samarskogo nauchnogo tsentra Rossiyskoy akademii nauk. 2013;15(3-2):741-3.

29. Natural Medicines. Onion. Professional Monograph. 2020. Available from: https://naturalmedicines.therapeuticresearch.com/.

30. Natural Medicines. Garlic. Professional Monograph. 2020. Available from https://naturalmedicines.therapeuticresearch.com/.

31. Miravalova GSh, Kurbonbekova ShSh. Mirzorakhimov AK, Sattorov S, Dz haborova SS. Antioksidantnaya aktivnost' i soderzhanie polifenolov v Artemisia scoparia Waldst. Et kit, proizrastayushchey v usloviyakh zapadnogo Pamira [Antioxidant activity and content of polyphones in Artemisia scoparia Waldst. Et kit, growing under the conditions of Westerns Pamir]. Vestnik Avitsenny [Avicenna Bulletin]. 2018;20(4):416-20. Available from: https://doi. org/10.25005/2074-0581-2018-20-4-416-420.

32. Satorov S, Mirzoeva FD. Izuchenie antibakterial'noy aktivnosti luka Oshanina, proizrastayushchego v razlichnykh regionakh Respubliki Tadzhikistan [The study of the antibacterial activity of Allium Oschanii, growing in various regions of Tajikistan]. Medical Science of the XXI Century-Looking Towards the Future; 2019 November 29; Dushanbe, RT. Dushanbe: Izd-vo TGMU; 2019. p. 250-1.

33. Navruzshoev D. Redkie $i$ ischezayushchie vidy flory $i$ fauny Gorno-Badakhshanskoy Avtonomnoy Oblasti Respubliki Tadzhikistan [Rare and endangered species of flora and fauna of the Gorno-Badakhshan Autonomous Region of the Republic of Tajikistan]. Dushanbe, RT: Torus; 2013. 288 p.

34. Fritsch RM, Blattner FR, Gurushidze M. New classification of Allium L. subg. Melanocrommyum (Webb \& Berthel.) Rouy (Alliaceae) based on molecular and morphological characters. Phyton (Horn). 2010;49(2):145-220.

35. Li Q-Q, Zhou S-D, He X-J, Yu Y, Zhang Y-C, Wei X-Q. Phylogeny and biogeography of Allium (Amaryllidaceae: Allieae) based on nuclear ribosomal internal transcribed spacer and chloroplast rps16 sequences, focusing on the inclusion of species endemic to China. Annals of Botany. 2010;106(5):709-33.

36. Fritsch RM. A preliminary review of Allium subg. Melanocrommyum in Central Asia. Leibniz-Institut für Pflanzengenetik und Kulturpflanzenforschung Gatersleben (IPK). Gatersleben; 2016. p. 1-288.

37. Gómez LG, Sánchez-Muniz FJ. Revisión: Efectos cardiovasculares del ajo (Allium sativum). Arch Latinoam Nutr. 2000;50(3):219-29.

38. Teshika JD, Zakariyyah AM, Zaynab T, Zengin G, Rengasamy KR, Pandian SK, et al. Traditional and modern uses of onion bulb (Allium cepa L.): a systematic review. Critical Reviews in Food Science and Nutrition. 2019;59(sup1):S39-S70.

39. Kabrah MAM, Faidah HS, Ashshi AM, Turkistani MSA. Antibacterial Effect of Onion. Sch J App Med Sci. 2016;4:4128-33.

40. 4Yetgin A, Canli K, Altuner EM. Comparison of antimicrobial activity of Allium sativum Cloves from China and Taşköprü, Turkey. Advances in Pharmacological Sciences. 2018;2018:1-5. 
41. Benkeblia N. Antimicrobial activity of essential oil extracts of various onions (Allium cepa) and garlic (Allium sativum). LWT - Food Science and Technology. 2004;37(2):263-8.

42. Simin N, Mitić-Ćulafić D, Pavić A, Orcic D, Nemes I, Cetojevic-Simin D, et al. An overview of the biological activities of less known wild onions (genus Allium sect. Codonoprasum). Biologia Serbica. 2020;41(2).

43. Mnayer D, Fabiano-Tixier A-S, Petitcolas E, Hamieh T, Nehme N, Ferrant C, et al. Chemical composition, antibacterial and antioxidant activities of six essentials oils from the Alliaceae family. Molecules. 2014;19(12):20034-53.

44. Agrawal H, Ranjan S, Kishore G, Bhatt J, Gupta S. In vitro antibacterial activity of Allium humile. Academic Arena. 2010;2:83-6.

45. Shams-Ghahfarokhi M, Shokoohamiri M-R, Amirrajab N, Moghadasi B, Ghajari A, Zeini F, et al. In vitro antifungal activities of Allium cepa, Allium sativum and ketoconazole against some pathogenic yeasts and dermatophytes. Fitoterapia. 2006;77(4):321-3.

46. Pârvu M, Pârvu AE, Roşca-Casian O, Vlase L, Groza G. Antifungal activity of Allium obliquum. J Med Plants Res. 2010;4(2):138-41.

47. Bayan L, Koulivand PH, Gorji A. Garlic: a review of potential therapeutic effects. Avicenna Journal of Phytomedicine. 2014;4(1):1-14.

48. Stajner D, Varga ISI. An evaluation of the antioxidant abilities of Allium species. Acta Biological Szegediensis. 2003;47(1-4):103-6.

49. Petropoulos SA, Di Gioia F, Polyzos N, Tzortzakis N. Natural antioxidants, health effects and bioactive properties of wild Allium species. Current Pharmaceutical Design. 2020.
50. Lenkova M, Bystrická J, Tóth T, Hrstkova M. Evaluation and comparison of the content of total polyphenols and antioxidant activity of selected species of the genus Allium. Journal of Central European Agriculture. 2016;17(4):111933.

51. Takahashi M, Shibamoto T. Chemical compositions and antioxidant/anti-inflammatory activities of steam distillate from freeze-dried onion (Allium cepa L.) sprout. Journal of Agricultural and Food Chemistry. 2008;56(22):10462-7.

52. Mikaili P, Maadirad S, Moloudizargari M, Aghajanshakeri S, Sarahroodi S. Therapeutic uses and pharmacological properties of garlic, shallot, and their biologically active compounds. Iranian Journal of Basic Medical Sciences. 2013;16(10):1031-48.

53. Takaeva ShK, Karomatov ID. Herb leek. Biologiya i integrativnaya meditsina. 2017;5:232-8.

54. Karomatov ID, Razhabova NB. Garlic as remedy of ancient and modern medicine. Biologiya i integrativnaya meditsina. 2019;3:174-203.

55. Golubkina NA, Seredin TM, Molchanova AV, Kosheleva OV. Sravnitel'naya otsenka pokazateley antioksidantnoy aktivnosti nekotorykh vidov mnogoletnikh lukov [Comparative evaluation of the antioxidant activity of some types of perennial onions]. Ovoshchi Rossii. 2018;5:73-6.

56. Mahboubi A, Kamalinejad M, Ayatollahi AM, Babaeian M. Total phenolic content and antibacterial activity of five plants of Labiatae against four foodborne and some other bacteria. Iranian Journal of Pharmaceutical Research. 2014;13(2):559-66.

\section{(i) AUTHOR INFORMATION}

Satorov Saidbeg, Doctor of Medical Sciences, Professor, Head of the Department of Microbiology, Immunology and Virology, Avicenna Tajik State Medical University

SCOPUS: 10419425154

Researcher ID: S-9073-2016

ORCID ID: 0000-0003-1101-1840

Author ID: 78634

SPIN: 2523-8682

E-mail: sattorion@mail.ru

Mirzoeva Fazila, Assistant, Department of Microbiology, Immunology and Virology, Avicenna Tajik State Medical University

ORCID ID: 0000-0003-0187-0334

E-mail: fazila.mirzoeva88@mail.ru

Kurbonbekova Shifo, Senior Researcher, Institute of Botany, Physiology and Genetics of Plants, National Academy of Sciences of the Republic of Tajikistan ORCID ID: 0000-0001-7499-793x

E-mail: sh.k-biomed@yahoo.com

Satorov Shukhrat, Intern of the Department of Plant Biology, School of Environmental and Biological Sciences, Rutgers University

SCOPUS: 1742026179

ORCID ID: 0000-0003- 3072-1135

E-mail: sufion@mail.ru

Vakhidova Manizha, Intern of the Department of Plant Biology, School of Environmental and Biological Sciences, Rutgers University

ORCID ID: 0000-0002-3366-1580

SPIN: 9366-9702

E-mail: sufion@mail.ru

Dushenkov Vyacheslav, PhD, Associate Professor at the Department of Natural Sciences, Hostos Community College, City University of New York SCOPUS: 6507356097

Researcher ID: AAE-8520-2019

ORCID ID: 0000-0001- 5176-7461

Author ID: 638952

SPIN: 50533-0988

E-mail: dushenkov@sebs.rutgers.edu

\section{СВЕДЕНИЯ ОБ АВТОРАХ}

Саторов Саидбег, доктор медицинских наук, профессор кафедры микробиологии, иммунологии и вирусологии, Таджикский государственный медицинский университет им. Абуали ибни Сино

SCOPUS: 10419425154

Researcher ID: S-9073-2016

ORCID ID: 0000-0003-1101-1840

Author ID: 78634

SPIN код: 2523-8682

E-mail: sattorion@mail.ru

Мирзоева Фазила, ассистент кафедры микробиологии, иммунологии и вирусологии, Таджикский государственный медицинский университет им. Абуали ибни Сино

ORCID ID: 0000-0003-0187-0334

E-mail: fazila.mirzoeva88@mail.ru

Курбонбекова Шифо, старший научный сотрудник, Институт ботаники, физиологии и генетики растений, Национальная академия наук Таджикистана

ORCID ID: 0000-0001-7499-793x

E-mail: sh.k-biomed@yahoo.com

Саторов Шухрат, стажёр кафедры биологии растений, Школа экологических и биологических наук, Ратгерский Университет

SCOPUS: 1742026179

ORCID ID: 0000-0003-3072-1135

E-mail: sufion@mail.ru

Вахидова Манижа, стажёр кафедры биологии растений, Школа экологических и биологических наук, Ратгерский Университет

ORCID ID: 0000-0002-3366-1580

SPIN код: 9366-9702

E-mail: sufion@mail.ru

Душенков Вячеслав, доктор медицинских наук, профессор кафедры естественных наук, Хостоский общественный колледж, Городской Университет Нью-Йорка

SCOPUS: 6507356097

Researcher ID: AAE-8520-2019

ORCID ID: 0000-0001- 5176-7461

Author ID: 638952

SPIN код: 50533-0988

E-mail: dushenkov@sebs.rutgers.edu 
Information about the source of support in the form of grants, equipment, and drugs

The authors did not receive financial support from manufacturers of medicines and medical equipment

Conflicts of interest: The authors have no conflicts of interest

\section{ADDRESS FOR CORRESPONDENCE:}

\section{Satorov Saidbeg}

Doctor of Medical Sciences, Professor, Head of the Department of Microbiology, Immunology and Virology, Avicenna Tajik State Medical University

734003, Republic of Tajikistan, Dushanbe, Rudaki Ave., 139

Tel.: +992 (987) 842424

E-mail: sattorion@mail.ru

\section{AUTHOR CONTRIBUTIONS}

Conception and design: SS, DV

Data collection: MF, KSh, SSh, VM

Statistical analysis: SSh, VM

Analysis and interpretation: SS, MF, KSh, VM

Writing the article: MF, DV

Critical revision of the article: SS, DV

Overall responsibility: SS

\section{ACKNOWLEDGMENTS}

The research, reported in this publication and in the previous publication of the authors (Satorov S, Mirzoeva F, Satorov Sh, Vakhidova M, Dushenkov V. Comparative characteristics of antibacterial activity of plants growing in the central part of the Republic of Tajikistan. Vestnik Avitsenny [Avicenna Bulletin]. 2019;21(4):643-54.), was supported by the Fogarty International Center of the National Institutes of Health under Award Number D43TW009672. The content is solely the responsibility of the authors and does not necessarily represent the official views of the National Institutes of Health
Submitted
14.01.2020
Accepted
26.03.2020

Информация об источнике поддержки в виде грантов, оборудования лекарственных препаратов

Финансовой поддержки со стороны компаний-производителей лекар ственных препаратов и медицинского оборудования авторы не получали

Конфликт интересов: отсутствует

\section{АДРЕС ДЛЯ КОРРЕСПОНДЕНЦИИ:}

\section{Саторов Саидбег}

доктор медицинских наук, профессор кафедры микробиологии, иммунологии и вирусологии, Таджикский государственный медицинский университет им. Абуали ибни Сино

734003, Республика Таджикистан, г. Душанбе, пр. Рудаки, 139 Тел.: +992 (987) 842424

E-mail: sattorion@mail.ru

\section{ВКЛАД АВТОРОВ}

Разработка концепции и дизайна исследования: СС, ДВ Сбор материала: МФ, КШ, СШ, ВМ

Статистическая обработка данных: СШ, ВМ

Анализ полученных данных: СС, МФ, КШ, ВМ

Подготовка текста: МФ, ДВ

Редактирование: СС, ДВ

Общая ответственность: СС

\section{БЛАГОДАРНОСТИ}

Данное исследование, равно как и предыдущее (Satorov S, Mirzoeva F, Satorov Sh, Vakhidova M, Dushenkov V. Comparative characteristics of antibacterial activity of plants growing in the central part of the Republic of Tajikistan. Vestnik Avitsenny [Avicenna Bulletin]. 2019;21(4):643-54), выполнено при поддержке Fogarty International Center of the National Institutes of Health (грант № D43TW009672). Содержание работы является исключительно ответственностью авторов и не обязательно отражает официальные взгляды National Institutes of Health

$\begin{array}{ll}\text { Поступила } & 14.01 .2020 \\ \text { Принята в печать } & 26.03 .2020\end{array}$

